\title{
The Curies in colour
}

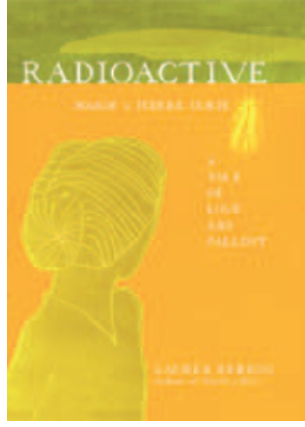

Radioactive:

Marie \& Pierre

Curie - A Tale

of Love and

Fallout

by Lauren Redniss

IT BOOKS: 2010.

208 PP. US\$29.99

auren Redniss's book Radioactive literally glows: its cover has, the _ publishers boast, been printed with luminescent ink. After several minutes of hard looking with the lights off, I did eventually convince myself that a small image was shimmering in the darkness rather than in my imagination. Once inside, the book genuinely does deliver the dazzling artwork that is promised. Redniss, a professional illustrator and writer, has individually designed every double-page spread to create a sumptuous riot of colours, drawings and photographs that jostle against each other to capture an idle browser's attention.

As if in an updated version of William Blake, uneven, almost childlike letters and ethereal elongated figures waver across vibrantly hued backdrops. For his own distinctive blend of words and images, Blake invented a special printing technique that made his illuminated books look as if they were hand-crafted, even though they had been printed from copper plates. In a similar bid for technical innovation and illusory naivety, Redniss has resurrected the cyanotype process, a type of photography achieved without a camera. Instead, a black and white image is pressed tightly against specially treated paper, and then exposed to sunlight, whose ultraviolet rays create densely coloured deposits of ferric ferrocyanide. Either with or without additional hand-tinting, the deep blue pictures that result shine with an inner luminosity, said by Redniss to be reminiscent of radioactivity itself. What's more, she reports unconvincingly, this particular chemical imbues her creation with added poignancy by being an approved treatment for internal contamination with radioactive metals.

Meandering through the pages are two intertwined plot-lines: Marie Curie’s love life, and the consequences of research into radioactivity. No sentimental novelist could have dreamt up a more romantic story than the Curie marriage as described here: young Polish woman falls in love with her supervisor; battling against poverty and ridicule, they work long hours together in the laboratory and make stupendous discoveries; at home, they had as near 2.2 children as possible; then he dies in a road accident; her subsequent affair with his former student leads to duels and a trial; she struggles on alone before sacrificing her life to radioactivity, a martyr to the science they both loved as fervently as each other.

Interspersed with this chronological account of Curie's life are episodes in the history of nuclear energy, some of which took place long after she died. Unsurprisingly, Redniss focuses on disasters - Hiroshima, Chernobyl, Three Mile Island - which are so much easier to write about evocatively (and one-sidedly) than the peaceful uses of reactors. To my mind, juxtaposing these events against scenes in the Curies' research seems a cheap way of attributing blame by association, rather like holding Benjamin Franklin responsible for the electric chair or Gregor Mendel for Dolly the sheep.

In passing, Redniss mentions that Curie, ill and publicly reviled, sought refuge in London with her friend Hertha Ayrton, an electrical expert. This feisty physicist was nominated for fellowship of the Royal Society, but turned down on the grounds that she was married. Like Curie, Ayrton despised discrimination in science, and she told a journalist: "I do not agree with sex being brought into science at all. The idea of 'woman and science' is completely irrelevant. Either a woman is a good scientist or she is not; in any case, she should be given opportunities, and her work should be studied from the scientific, not the sex, point of view."

Rather than pursuing such themes, Redniss opens with an apology that curiously undermines her own project by quoting Curie's pronouncement that "There is no connection between my scientific work and the facts of private life." Perhaps Redniss is trying to salve a guilty conscience, given her book exposes how, for the Curies, science mingled with sex, permeating every aspect of their existence. Some recent appraisals present a more critical view of their relationship, but Redniss ignores those in favour of milking maximum emotion from the conventional version as originally told by one of their daughters.

Whatever the surface similarities, Redniss is no Blake. Whereas Blake envisaged himself as a saviour who would liberate struggling artists by enabling them to circumvent profit-hungry middlemen, Redniss takes full advantage of the opportunities offered by modern mass publishing. Blake's writing may look primitive, but he had to write it in mirror-image on an engraved metal plate; in contrast, Redniss's apparently hand-written text was actually printed. Based on the title pages of contemporary manuscripts, her deceptive custom-made type-face is named after Eusapia Palladino, an Italian spiritualist who attracted the Curies and other scientific luminaries to her séances in Paris. Monastic scribes spent years learning how to make blocks of text fit exactly into interesting shapes, but Redniss's computer did the calculations for her. How perverse, then, to have sacrificed legibility! Only a determined reader will bother reading the over-spaced words sprawling indistinctly across dark backgrounds.

This imaginative book must have been terrific fun to create - but who, I wondered, would want to read it? Flicking through the pages, I realized that I was asking the wrong question: publishers are in business to sell, not to educate. Luscious to gaze at, Radioactive easily outshines its competitors on the science shelves for all those perplexed aunts and uncles trying to pick an appropriate gift. Their relatives may be disappointed. Unlike those marvellous cartoon books that somehow contrive to condense the complexities of relativity or thermodynamics into balloon-size soundbites, this glossy book features large blocks of pedestrian text. Despite the extravagant use of space and colour, the science is explained in words, not pictures: in 200 pages, there is but one single diagram showing how nuclear fission can lead to a chain reaction. And the artwork? I can dream up plenty of positive adjectives striking, varied, colourful - but this is not a visual treasure. On the other hand, I have never been a great Blake fan.

\section{REVIEWED BY PATRICIA FARA}

Patricia Fara lectures at the University of Cambridge and is the author of many popular books on the history of science. 